\title{
NORBERTO BOBBIO E A DEMOCRACIA NOS DIÁLOGOS PLATÔNICOS
}

\section{NORBERTO BOBBIO ET LADEMOCRATIE CHEZ LES DIALOGUES PLATONICIENS}

Cristina de Souza Agostini'

RESUMO: O presente artigo busca mostrar de que modo algumas consideraçóes bobbianas sobre a democracia antiga e sobre a perspectiva filosófica platônica acerca do regime do demos mostram-se insuficientes para compreender a argumentaçâo socrática acerca da verdadeira política.

PALAVRAS-CHAVE: Diálogo; gênero; política; virtude.

RÉSUMÉ: L'article propose démontrer vers quel biais quelques considerations de Norberto Bobbio sur la démocratie ancienne et sur la perspective platonicienne du régime du demos ne sont pas suffisantes pour qui nous poussions comprendre l'argumentation socratique auprès de la vraie politique.

MOTS-CLÉS: Dialogue; genre; politique; virtue.

\section{INTRODUÇÃO}

A partir das consideraçôes que Norberto Bobbio elabora em dois textos, a saber o ensaio "A democracia dos modernos comparada à dos antigos (e à dos pósteros)" e nos dois primeiros capítulos de A teoria das formas de governo, ao longo desse artigo, pretendo desenvolver de que modo a diferenciaçăo que Bobbio faz entre democracia antiga e democracia moderna, centrada sobretudo na ideia de decisăo-escolha, no limite, abre uma importante brecha para se questionar o uso da nomenclatura grega "democracia" para os regimes democráticos contemporâneos. Após esse primeiro percurso argumentativo, voltando para os capítulos "Uma discussăo célebre" e "Platáo" de A teoria das formas de governo, discutir-se-á de que modo a ausência da metafísica platônica nesses dois capítulos explica, em grande parte, por que a argumentaçấo bobbiana se mostra insuficiente e lacunar quando se trata de compreender os motivos pelos quais as formas de governo apresentadas năo podem ser lidas sob uma perspectiva historicista, mas de acordo com o gênero dialógico.

Impossível parece ao estudioso que, de fato, se proponha a pensar a estrutura social na qual vive nâo repetir o que uma dezena de outros estudiosos já disseram. Com efeito, a análise criteriosa dos múltiplos eventos das sociedades, das inúmeras transformaçóes pelas quais nossos padrōes de comportamento se alteram adequando-se

Bacharelado, licenciatura, mestrado e doutorado pela USP. Professora da Universidade Săo Judas Tadeu 
às mudanças políticas, econômicas, religiosas, pedagógicas, ambientais e tecnológicas nunca dirá nada novo. Todo o arcabouço teórico necessário para a compreensáo dos fenômenos sociais já foi escrito. E, aliás, já foi escrito há muito tempo. A pesquisa filosófica, ou melhor, a atividade escrita da filosofia, é a sempre repetitiva retomada dos escritos de um filósofo que, provavelmente, nâo disse tudo e por isso, premente se faz o ajuste, a crítica, a interpretaçăo ou pretensa traduçăo de seu pensamento.

No entanto, tudo já foi dito. A falsa novidade reside em fazer crer que ainda é preciso continuar a busca por um melhor argumento. Aquele argumento infalível ou, na melhor das hipóteses, que consiga abarcar a maior parte dos fenômenos. A filosofia sem sua história peca por tentar refutar o princípio de náo-contradiçăo na medida em que os nomes que brilham na abóboda estrelada de sophia se apoiam uns sobre outros para poderem permanecer com a luz própria que a autonomia de um pensamento possui quando gestado em outro. O pensamento luminoso que brilha nesse céu da escrita filosófica é concebido. Para que haja concepçâo, para que haja nascimento, é necessário haver o já sendo que era antes do que virá como novo. Contudo, repito: o novo é enganoso porque sua condiçấo de possibilidade de existência é a vida do mais velho. E é a partir do mais velho, porque há o mais velho que o novo pode ser algo diferente daquele, mas ainda assim, o repete em forma. Todo o logos precisa de um pai, já ensinava o diálogo Fedro de Platăo. Toda a escrita filosófica se articula em torno das mesmas questōes. Como essas questóes sâo colocadas: isso é o que pode ser chamado novidade em filosofia. O como ao invés do por que é o rebento do filósofo.

E, se os textos clássicos já nos disseram tudo, se neles há tudo o que precisamos ter para dar à luz um pensamento autônomo, como fica o papel do pesquisador atual que já năo faz outra coisa a náo ser repetir os clássicos e declarar abertamente que seu pensamento só tem algum rigor porque está assentado sobre uma nâo anônima constelaçáo? Por que ainda continuar a escrever um artigo sobre algo que já foi escrito? Para fazer crer que se é capaz de oferecer uma nova interpretaçăo ou uma melhor elucidaçăo sobre aquilo que náo houvera ficado claro ou que passara desapercebido? A ingenuidade do pesquisador da atualidade literalmente mascara sua arrogância em ludibriar seus leitores de que ele seria capaz de acrescentar algo a um clássico. A supremacia da arrogância e do engodo é sugerir que ainda se escreve a fim de fazer com que o leitor compreenda "melhor" o clássico por meio da leitura de um artigo que comenta o clássico. Ninguém é comentador por filantropia, nem busca compreender nossas relaçóes sociais para tornar o mundo mais justo e igualitário, com o final feliz que apenas os contos de fada de narrativa oca săo capazes de proporcionar. É em busca da satisfaçấo intelectual que o genuíno pesquisador da filosofia escreve. Essa satisfaçăo é pessoal e egoísta. Caso haja o afă transformador no comentador filosófico, este já năo é mais alguém que apenas escreve. Ele também sai às ruas e vive, assumindo a identidade que lhe é própria: a de ser humano, e a cisăo entre academia e vida comum perde sua razâo de ser. Mas isso já é uma outra história.

Assim, nesse artigo, torna-se impossível escrever algo novo. A condiçấo de possibilidade da escrita de um artigo acadêmico é precisamente a repetiçâo. O que será abordado por meio de minha escrita repete de modo muito opaco o brilho de um pensamento, efetivamente, epifânico, de um lado e, de outro lado, repete a tentativa de um comentador em tentar esclarecer o que já foi dito pelo autor clássico. Ora, quanto ao efetivo pensamento, este disse tudo e ilumina a céu filosófico. Quanto ao comentador 
que tentou esclarecer a estrela, obviamente cometeu o suicídio intelectual na medida em que nenhuma luz mortal consegue ser tăo esplendorosa quanto aquela que provém do alto. No entanto, ele fez o que lhe era possível: ainda repetir e se apoiar sobre o clássico. Citando o clássico e procurando compreendê-lo para si mesmo, agiu em busca de sua egoística satisfaçáo intelectual e, com ela, proporcionou material para continuar a repetir a leitura do clássico pela via do comentário.

A busca pela falsa melhor compreensăo do comentário ou pela refutaçáo deste é a desculpa de todos os acadêmicos para atender à demanda da escrita que provoca o gozo despreocupado com uma contraparte inexistente. Atividade sempre egoísta. Assim, porque pertenço ao conjunto daqueles e daquelas que procuram gozar para si mesmos, repete-se o que todos os acadêmicos fazem: repetem-se.

É para escrever sobre Platăo que se escreverá sobre Norberto Bobbio. É com o intuito de demonstrar que as argumentaçôes de Bobbio se mostram, por vezes, falhas porque descuram da metafísica platônica que se articula um programa em que Bobbio se torna o centro de uma discussáo para configurar-se somente em um expediente para satisfazer o desejo pelo clássico. Desse modo, o próprio Bobbio agiu quando se apoiou sobre os clássicos para conseguir escrever. Contudo, como sou do grupo daquelas que simulam algum comprometimento com a ideia de que é necessário sempre propor uma nova interpretaçăo do texto ou de que é possível sempre oferecer uma melhor proposta que refute o comentário anterior é que escreverei. Sem tal desculpa medíocre, a pesquisa torna-se inviável e, portanto, toda a produçâo acadêmica seria inexistente. Começa-se, entăo, a náo escrever nada que já năo tenha sido escrito, repito.

É sobre uma parte de um capítulo específico de Teoria geral da política de Bobbio que me deterei. Trata-se do primeiro momento de "Democracia: os fundamentos", mais especificamente do subtítulo "A democracia dos modernos comparada à dos antigos (e à dos pósteros)". Ali, tem-se uma diferenciaçấo entre o uso descritivo e o uso valorativo do termo democracia para antigos e modernos. Segundo Bobbio, "no seu uso descritivo, por democracia os antigos entendiam a democracia direta, os modernos, a democracia representativa" (BOBBIO, 2000, p. 371). Por enquanto, atenhamo-nos ao uso descritivo que salienta o autor sobre o termo.

Assim, Bobbio continua afirmando que para os antigos, a imagem de democracia estava vinculada a uma praça ou assembleia em que os cidadáos eram convocados a tomar decisóes. "'Democracia' significava o que a palavra designa literalmente: poder do demos, e náo, como hoje, poder dos representantes do demos" (BOBBIO, 2000, p. 372). Nesse sentido, Bobbio atrela à democracia antiga a prerrogativa da decisấo que emana do povo acerca das questóes da polis. Que se entenda povo como a massa, os pobres, os muitos, nâo importa e náo encobre o fato de que a decisâo é sempre tomada pelos agentes que frequentam o local das discussóes dos assuntos que se referem à polis. Em outros termos, delegar a decisăo sobre os rumos da polis a outrem é completamente estranho aos agentes políticos antigos. No entanto, Bobbio para aí: ele insiste na importância do demos para a constituiçăo da democracia antiga, mas se esquece de dar necessária atençăo ao kratos.

Em seu Vocabulário das instituiçōes indo-europeias, Émile Benveniste elabora uma importante investigaçấo acerca do termo kratos. Ocupando-se da maneira 
segundo a qual o vocábulo aparece na narrativa homérica, o linguista nos aponta o fato de que kratos deve ser pensado além do chavâo poder, mas como superioridade, prevalência no combate ou assembleia. Caso kratos seja pensado enquanto poder, este deve circunscrever uma potência territorial ou política (BENVENISTE, 1969, p. 80). O verbo infinitivo kratein significa ser mestre, ser dono de si, possuir a autoridade e, por equivalência, podemos pensar que a democracia é o regime em que o demos possui, de fato, a autoridade de decisáo e é mestre de si, ou seja, sabe o que faz, porque é ele quem faz. Assim, quando transposta para nossos dias, a democracia dos antigos náo encontra referencial, pois a democracia moderna, sendo representativa, pressupóe que quem decidirá sobre as açōes a serem tomadas no campo político sấo algumas pessoas que foram eleitas por meio do voto para ocuparem tal funçấo. Seguindo os desdobramentos disso, tem-se que na democracia representativa está ausente o sustentáculo da democracia dos antigos: a decisăo acerca dos assuntos políticos empreendida pelo corpo demótico. Na democracia antiga, o demos é senhor de si, năo necessita de um representante para responder por ele, pois a própria ideia de representaçáo é contraditória àquela de autoridade ou supremacia no ato decisório. Enquanto "o voto ao qual se costuma associar o relevante ato de uma democracia atual, é o voto năo para decidir, mas sim para eleger quem deverá decidir" (BOBBIO, 2000, p. 372), as votaçóes que ocorriam na Pnyx decidiam questōes prementes para a organizaçăo das relaçôes sociais em Atenas. Com efeito, as eleiçóes náo estavam excluídas da agenda democrática ateniense, mas elas tinham um outro caráter. Eram pensadas enquanto expediente de "correçâo do poder direto do povo" (BOBBIO, 2000, p. 374) atribuindo algumas magistraturas de acordo com critérios eletivos.

A democracia antiga sempre foi concebida como governo exercido diretamente pelo povo e, assim, toda a crítica antiga sobre esse regime político se estrutura sobre a noçăo de que quem exerce a supremacia nos assuntos da polis é diretamente o povo. Quem escolhe os próximos passos da vida social ateniense sāo os próprios atenienses em conjunto.

Com efeito, esse é o fator de extrema relevância tanto para a análise platônica quanto para a que Aristóteles faz sobre a democracia. O que tais análises levam em consideraçăo é que a democracia é um regime em que a maior parte da cidade, a saber, os pobres, governam diretamente. A transferência da escolha para outrem é completamente estranha aos antigos e, entâo, cabe a nós repensarmos nossa insistência em atrelar a Atenas o regime moderno que necessariamente pressupóe a representaçấo como essencial de sua estrutura operacional.

O fato é que, como salienta Bobbio, a despeito de outras conclusōes às quais ele pode ter chegado, o termo democracia apresenta carga extremamente positiva: "nâo há regime, mesmo o mais autocrático, que năo goste de ser chamado de democrático" (BOBBIO, 2000, p. 375). Democracia hoje tem um sentido valorativo que vem em primeiro plano, talvez até antes de sua descriçăo. E, enquanto um valor, identificar-se a mecanismos democráticos, significa, literalmente, valorizar-se, pois a democracia é melhor que a ditadura ou que qualquer outro regime que prescinda de eleiçóes.

Ora, esse năo é o caso para os autores antigos. Para Platăo e Aristóteles, a democracia é uma forma desviada de governo em sentido moral. Na democracia, o governo é exercido pelos pobres que, desde os tempos mais remotos, constituem a maior parte da populaçấo, e estabelecem leis de acordo com seus interesses, prejudicando 
o restante da comunidade política, a saber, os ricos. Para a filosofia grega clássica, assim como na oligarquia ou na tirania, os agentes que estăo à frente de cargos públicos, na democracia, governam em benefício próprio, pois nâo săo dotados de excelências necessárias para a vida em comunidade, como as virtudes de amizade e justiça. A concepçăo dos filósofos antigos sobre a política ancora-se na pressuposiçăo de que o bom governante só é bom porque apresenta virtudes intrínsecas que o fazem bom em qualquer campo da vida moral. Daí, entăo, a separaçăo das esferas pública e privada ser concernente à separaçấo de configuraçóes distintas da vida dos cidadâos. Que a ambientaçăo particular do oikos se refira ao espaço de convivência da família e o campo da polis à convivência com outros cidadáos năo leva os filósofos antigos a desdobrarem a possibilidade de que o político justo será um marido, pai e senhor que espanca mulher, filhos e escravos para demonstrar sua autoridade ou coisa que o valha. Na medida em que o alcance da felicidade implica em uma completude virtuosa, a cisâo entre público e privado consiste na separaçăo entre os problemas relacionados à manutençấo da casa daqueles relacionados à manutençấo da polis. Para uma sociedade como a nossa, cujas redes sociais e os meios de comunicaçăo de massa săo o ápice do divertimento nos intervalos do trabalho repetitivo imposto pelo capitalismo industrial, fica difícil imaginar em que consiste a tăo afamada vida privada, embora essa seja a grande tônica da modernidade, a saber, a devoçâo à privacidade e à cessâo das decisóes concernentes à vida pública a representantes.

Desse modo, segundo Bobbio, para os antigos, o uso valorativo da democracia é negativo, enquanto para os modernos, é positivo. Mas é preciso circunscrever para quais antigos a democracia é, como disse, uma forma degenerada de governo. Com efeito, ela o é, certamente, para Platăo e Aristóteles, mas é difícil acreditar que Alcibíades, Laques, Agatăo ou Aristófanes concordem com a perspectiva dos dois filósofos.

Assim como muitos autores, Bobbio desliza nas generalizaçóes. Enquanto disserta acerca da conotaçăo negativa que a democracia antiga apresenta, como no trecho em que escreve que "o juízo predominante sobre essa forma de governo foi, a começar pela Antiguidade, negativo" (BOBBIO, 2000, p. 375), esquece-se de que para fundamentar tal asserçâo, vale-se basicamente de dois pontos de vista filosóficos que pressupóem que a excelência da alma é condiçăo indispensável para a atividade política, deixando de lado uma pluralidade de fontes que ao invés de atribuírem conotaçôes moralmente intrínsecas ao regime a partir de um paradigma de virtude, buscam na efetividade democrática apontar quais săo as mazelas que devem ser sanadas e os benefícios que precisam ser preservados para que o corpo político se fortaleça. Quando Bobbio se vale da filosofia de Platâo e de Aristóteles para concluir que na Antiguidade a democracia é pensada de modo negativo em decorrência de sua descrição, engana-se. Se Platăo tece uma análise em que o regime democrático é corrompido, é porque tem como paradigma uma metafísica do bem e nâo porque, como argumenta Bobbio, "a democracia sempre foi concebida unicamente como governo direto do povo" (BOBBIO, 2000, p. 375). Ora, já no caso de Aristóteles, ela é a forma corrupta da politeia, pois a justiça política que declara que o governo deve estar a serviço de toda a comunidade é violentada com o governo que se faz em benefício daqueles que ocupam os cargos públicos. Nesse sentido, para Aristóteles, a politeia, assim como a democracia, também é exercida diretamente pelos muitos cidadăos 
que governarăo em prol de toda a polis. A diferença entre as duas recai no fato de que na primeira, as decisóes săo tomadas em favor de toda a comunidade política, enquanto na segunda, as decisóes prezam somente quem está no comando da vida pública. Desse modo, percebemos como a falta de rigor com que Bobbio apresenta o texto filosófico compromete muito as conclusóes às quais chega sobre as fontes gregas das quais se vale.

No primeiro capítulo de A teoria das formas de governo, a discussăo que ocorre no terceiro livro das Histórias de Heródoto, entre os parágrafos 80-82, é trazida por Bobbio a fim de demonstrar de que modo os persas Otanes, Megabizes e Dario desenvolvem argumentos para sustentar uma melhor forma de governo para o povo persa e impedir os mandos e desmandos de homens que agem apenas em benefício próprio. Ali, tem-se a célebre conversa na qual cada interlocutor defende um tipo de governo atrelado ao número de pessoas que estará à frente na conduçāo dos negócios públicos. Assim, argumenta-se em favor da isonomia, da oligarquia e da monarquia, diferenciando-as acerca de quem está no poder, mas assinala-se o fato de que, em comum, todas as formas possuem a característica preocupaçăo com o bem de todos os cidadăos. Explico: embora cada interlocutor saia em defesa de um tipo de regime político e condene os outros dois, tanto a defesa quanto a acusaçáo partem do mesmo princípio, a saber, o de que o bom governo é aquele que preza o bem comum. Nesse sentido, a defesa desenvolvida por Otanes, Megabizes e Dario, respectivamente, em favor da isonomia, oligarquia e monarquia concentra-se no ponto de que os agentes que estarăo à frente da conduçấo desses regimes agirăo de acordo com a justiça pública. No entanto, a condenaçấo dos outros dois regimes pressupóe que lhes falta a mesma justiça e, entâo, o que se pode esperar é que sempre a corda tenda apenas para um lado da comunidade política, prejudicando parte da populaçăo.

Ora, o que se procura nessa discussăo é encontrar uma forma que atenda às necessidades de todos os cidadăos, beneficiando a cidade como um todo, pois, como diz Otanes: "vimos até que ponto chegou a prepotência de Cambises, e sofremos depois a dos magos" (BOBBIO, 1985, p. 39). Com efeito, é porque os últimos governantes agiram em benefício próprio que é preciso sustentar um regime que salvaguarde a justiça pública, para que os males da política feita por usurpadores do bem comum năo se repita. Nesse sentido, defender uma das três formas para cada um dos interlocutores resulta em estar ao lado de todos os cidadáos. $O$ ataque às duas formas que restam para cada um desses interlocutores persas equivale a condenar, por meio de argumentos, formas de governo concebidas como modos de se fazer política cujo objetivo está em satisfazer aos interesses dos governantes às custas do restante da populaçấo.

Em Heródoto, a pergunta sobre qual seria, portanto, a melhor forma de governo depende da nossa concordância com os argumentos elencados pelos persas. É partindo de formas reais de conduçăo política que os três personagens tentam convencer uns aos outros de que o regime que defendem é melhor do que os dos outros dois. Nas três possibilidades, encontramos bons e maus motivos para que elas sejam escolhidas daqui por diante, após Cambises e os magos. É preciso, portanto, pesar os argumentos dos persas e extrair daí uma opçâo que náo encontra qualquer garantia exterior à própria prática política de que a justiça será o eixo que conduzirá os dirigentes. 
Tal perspectiva sobre formas de governo năo encontra respaldo nos textos de filosofia política de Platâo e de Aristóteles. Com efeito, para o primeiro, a metafísica que fundamenta a política inviabiliza qualquer possibilidade de regime voltado para o bem comum que náo sejam a monarquia ou a aristocracia filosófica. Já para o segundo, cuja discussâo política se dá em campo próprio, desvinculado do conhecimento relativo às coisas necessárias e imutáveis, o governo em prol do bem comum pressupóe que aquele ou aqueles que estejam no comando da polis sejam virtuosos para executarem boas açôes. É porque a virtude é condiçâo necessária para o exercício do governo justo, independentemente, do número de indivíduos que ocupe os cargos públicos, uma vez que ela funciona como um regulador das açóes, que se torna imprescindível condiçâo para a política. Assim, é de acordo com a quantidade de homens virtuosos no poder que a boa política é classificada. Quando quem ocupa os cargos públicos sâo os viciosos, necessariamente, tem-se uma forma degenerada de governo, já que ao invés de beneficiar a todos os cidadāos, ela tem em mira satisfazer os desejos daqueles que governam. E, embora Platăo e Aristóteles apresentem argumentos bastante diferentes e, na maior parte das vezes, divergentes sobre o campo político, na medida em que os pontos de partida dos quais se valem para o estabelecimento da melhor vida em comunidade sejam completamente diversos, ainda assim, ambos consideram a virtude elemento essencial e indispensável para a conduçâo da polis. Essa virtude política verifica-se na açăo daquele que governa "em prol da comunidade". Ora, os antigos nos ensinam que estar à frente da direçấo pública năo tem nada a ver com enriquecimento ou privilégios, mas a situaçăo daquele ou daqueles que governam é a de se colocar a todo o momento à frente de sua comunidade, protegendo-a contra as investidas externas, sanando sediçōes internas, distribuindo a justiça de modo igualitário. Em outros termos, o governante virtuoso tem muito mais a perder em termos materiais que a ganhar. Seu governo năo é para si, mas para todos os que compóem o corpo da polis. Ora, a compreensăo que o governante tem acerca do porquê é ele quem deve governar, dentro do escopo de que esse porquê se refere à administraçấo e garantia do bem comum só é possível a quem, de fato, possui a excelência de alma e, portanto, é bom.

Desse modo, a fim de compreendermos melhor o fundamento da crítica que o personagem Sócrates da República, de Platăo, tece à democracia e a qualquer regime que năo seja conduzido por filósofos, voltemo-nos para o segundo capítulo de A teoria das formas de governo a fim de mostrar de que modo a leitura que Bobbio elabora sobre a rejeiçấo platônica ao regime do demos revela muito mais seus próprios juízos de valor do que, propriamente, se atém à compreensâo do gênero textual ao qual pertence a República, por um lado e, por outro, desconsidera o fundamento metafísico no qual se estrutura a argumentaçāo filosófica empreendida por Sócrates e seus interlocutores.

\footnotetext{
Na verdade, Platăo - como todos os grandes conservadores, que sempre veem o passado com benevolência e o futuro com espanto - tem uma concepçáo pessimista da história (uma concepçáo "terrorista", como diria Kant). Vê a história năo como progresso indefinido mas, ao contrário, como regresso definido; năo como uma passagem do bem para o melhor, mas como um regresso do mal para o pior. Tendo vivido na época da decadência da gloriosa democracia ateniense, examina, analisa e denuncia a degradaçáo da pólis: năo o seu esplendor. É também - como todos os grandes conservadores - um historiador (e um moralista) da decadência das naçôes, mais do que da sua grandeza. Diante da degradaçăo contínua da história, a soluçăo
} 
só pode estar "fora" da história, atingível por um processo de sublimaçăo que representa uma mudança radical (a ponto de levantar a suspeita de que a história năo é capaz de recebê-la e de suportá-la) com relaçáo ao que acontece de fato no mundo. (BOBBIO, 1985, p. 46)

Caracterizar Platâo como conservador a partir de um diálogo como A República é, no mínimo, ousado. Com efeito, é lá que Sócrates expōe a Glauco e a Adimanto as polêmicas teses que sâo requisito imprescindível para a configuraçăo da kalipolis, a saber, a educaçăo mista, a comunidade de mulheres, bens e filhos e o governo filosófico. Ora, cada uma dessas asserçōes, chamadas por Sócrates de "ondas", refletem de que modo o exercício que o mestre de Platăo em conjunto com os irmáos deste último, na tentativa de estruturar a melhor polis, mostra-se na contracorrente de todos os valores comumente aceitos pela comunidade a qual pertencem. Assim, é preciso que Sócrates apresente argumentos que o tornem hábil nadador, livrando-o do afogamento que esperam aqueles que năo conseguem fundamentar argumentos. É preciso a Sócrates conseguir persuadir seus interlocutores de que o presente e o passado replicam os mesmos vícios e que, portanto, apenas com uma ressignificaçáo completa de termos e endireitamento da postura do raciocínio será possível haver transformaçăo. Desse modo, para que nos apropriemos do argumento filosófico com maior acuidade, sugiro, primeiramente, atermo-nos ao gênero d'A República para, entăo, em um segundo momento, vislumbrarmos a discussâo dialógica em contraposiçăo às conclusōes bobbianas sobre Platăo.

A República, assim como os outros dois textos citados por Bobbio, Político e Leis, ${ }^{2}$ cuja autoria pode ser atribuída com determinada certeza ao filósofo Platăo, pertencem ao rol dos escritos em forma de diálogo. Ora, os diálogos platônicos apresentam personagens que conversam sobre algum tema, procurando encontrar meios seja de sustentar posiçôes, encontrar definiçôes, elogiar condutas ou, como no caso d'A República, considerar de que modo a cidade mais feliz deveria ser constituída. No gênero dialógico, os personagens interagem em um espaço e em um tempo essenciais tanto para o desenvolvimento da temática desdobrada quanto para o comportamento que desempenharăo durante as discussóes. Com efeito, o diálogo năo é um tratado filosófico, nem um ensaio no qual se apresentam argumentos e teses desenvolvidos por um autor que se responsabiliza pela adoçâo de uma posiçăo frente a um problema que demanda uma resposta, sobretudo quando, nesse diálogo, seu autor năo figura. ${ }^{3}$ Nos diálogos platônicos, Platăo nunca aparece enquanto personagem em açăo. N'A República, assim como na maioria dos diálogos, o centro das atençôes é Sócrates, que, tendo descido ao Pireu a fim de celebrar uma festa e dedicar preces à divindade, de repente, vê-se coagido por queridos amigos a nâo subir imediatamente de volta à sua casa na astus, mas, ao contrário, permanecer fora da cidade e ceder um pouco de tempo a eles na casa do meteco Céfalo. De fato, dificilmente Sócrates desce ao Pireu. Ele pouco sai do centro da cidade. Assim, quando seus amigos da periferia o veem por ali, é o momento de agarrá-lo e năo o deixar partir antes de terem desfrutado de

Político e Leis săo os outros dois textos platônicos além da República que Bobbio cita no capítulo "Platăo", de A teoria das formas de governo.

3 Tem-se um caso diferente nos diálogos escritos, por exemplo, por Agostinho de Hipona, tais quais De Ordine e De Magistro, por exemplo, em que o próprio Agostinho figura como personagem. 
sua luminosa presença que sempre traz o prazer de uma boa conversa. Desse modo, é preciso conduzir Sócrates à casa do velho Céfalo que, muito idoso, năo consegue mais subir a astus e, entăo, já há muito tempo năo vê Sócrates. Por sua vez, como dito, Sócrates quase náo desce à periferia e, portanto, porque ali se encontrava em uma festividade cultual, fora o momento mais que oportuno para que os amigos de fora matassem a saudade do amigo de dentro e, sem se preocupar com a duraçăo da conversa, aproveitar ao máximo a companhia daquele que perguntava e esperava uma resposta para, em seguida, perguntar outra vez e, a cada resposta encetar uma nova pergunta. Dialogar era o que os amigos de Sócrates mais desejavam e, afinal de contas, era apenas isso que Sócrates podia oferecer. O personagem delineado por Platăo, cuja pobreza testemunha sua inocência perante a acusaçáo de que ensina a tornar o discurso fraco forte, na Apologia, sinaliza para o fato de que o interesse que alguém demonstra para com ele năo pode ser outro que a sua companhia. Se os amigos querem conversar com Sócrates significa que o que querem do filósofo é estar junto dele, significa que o que querem é apenas ser interrogados. Apenas. Apenas esse é só o início da primeira camada do início da história.

Os personagens dos diálogos têm características psicológicas. No Górgias, vemos um Querefonte bastante afoito, n'A República, um Trasímaco deveras enraivecido e no Sumposium, um Alcíbiades completamente luxurioso. Antes de qualquer coisa, os diálogos de Platâo contam uma história. De modo análogo às narrativas de Homero e Hesíodo, os personagens elaborados por Platăo agem em um cenário e em um tempo que conferem ao leitor uma imagem da açăo dialógica que além de exigir o esforço intelectual para o acompanhamento da argumentaçăo, move nosso sentimento a concordar ou a discordar veementemente da situaçăo à qual os personagens se expóem durante as circunstâncias da conversa. Ora, a referência paidêutica dos contemporâneos de Platăo era a narrativa mítica. A maneira que o filósofo encontra para propor um novo paradigma paidêutico é o diálogo. Assim como o mito, o gênero dialógico conta com tempo, espaço e personagens. No entanto, diferentemente do mito, tal gênero coloca em cena o filósofo e um desdobramento argumentativo que nấo se conclui quando termina, pois o fim é um ponto de partida para uma nova pergunta.

Ainda estamos no início da primeira camada do início da história e ainda nem começamos a entrever a pergunta à qual devemos por força do dever de a pesquisa começar a tentar responder.

Nesse sentido, é melhor ater-se ao ponto que mais incomoda aquele que vê a história dilacerar-se na pena de um autor que dá cabo tanto da história contextual na qual o texto escrito insere-se quanto do gênero ao qual ele pertence, para ainda nâo dizer da metafísica constituinte de uma argumentaçăo que só significa porque a ontologia é condiçăo necessária de possibilidade para o discurso verdadeiramente significante. Assim, voltemo-nos à penúria a qual Bobbio submete Platăo.

Em substância, Platâo também aceita que haja seis formas de governo; destas, porém, reserva duas para a constituiçăo ideal e quatro para as formas reais que se afastam, em grau maior ou menor, da forma ideal. Das quatro constituiçóes corrompidas, a segunda, a terceira e a quarta correspondem exatamente às formas corrompidas das tipologias tradicionais - a oligarquia corresponde à forma corrompida da aristocracia, a democracia à "politeia" (como Aristóteles chamará o governo do povo na sua forma pura), a tirania à monarquia. (BOBBIO, 1985, p. 47) 


\begin{abstract}
Outra coisa a observar, no momento só incidentalmente (trata-se de assunto ao qual vamos voltar com frequência durante o curso), é o critério ou critérios com base nos quais Platăo distingue as formas boas das más. Relendo a passagem citada, veremos que esses critérios săo, em substância, dois: violência e consenso, legalidade e ilegalidade. As formas boas săo aquelas em que o governo năo se baseia na violência, e sim no consentimento ou na vontade dos cidadăos; onde ele atua de acordo com leis estabelecidas, e náo arbitrariamente. (BOBBIO, 1985, p. 54)
\end{abstract}

Acerca das duas citaçōes do texto bobbiano se fará alguns apontamentos com o intuito de demonstrar de que modo a descontextualizaçăo genérica e ontológica empobrecem e pulverizam o exercício do pensamento e argumentaçâo filosóficos. Assim, começo pelo primeiro extrato e, em seguida, detenho-me ao segundo para tăo logo concluir meu próprio exercício de repetiçăo acadêmica.

N'A República, o personagem Sócrates - e năo Platăo - juntamente com Glauco e Adimanto desenham a kalipolis, a bela cidade para, em seguida, articular as formas degeneradas de governo. Com efeito, diz Sócrates:

Se os filósofos năo forem reis nas cidades ou se os que hoje săo chamados reis e soberanos náo forem filósofos genuínos e capazes e se, numa mesma pessoa, năo coincidirem poder político e filosofia e năo for barrada agora, sob coerçăo, a caminhada das diversas naturezas que, em separado, buscam, uma dessas duas metas, năo é possível, caro Gláucon, que haja para as cidades uma trégua de males e, penso, nem para o gênero humano. (PLATÃO, A República, 473 d1-8)

Ora, se, e somente se, os filósofos dirigirem as cidades haverá efetivamente bom governo, pois apenas os filósofos conhecem os modelos de referência a partir dos quais os elementos essenciais para a boa vida em comunidade se perfazem. Os filósofos sâo os únicos indivíduos que sabem a maneira adequada segundo a qual devem agir em qualquer situaçăo política e que, além de possuir o conhecimento necessário para as açōes, efetivamente, agem. Devido ao conhecimento que apenas a atividade filosófica confere ao filósofo ou filósofa, esse gênero humano é o único que, de fato, se encontra apto para o exercício da política. Em outros termos, uma vez que a educaçăo filosófica é condiçâo necessária para o conhecimento da justiça, da amizade, da virtude e da paz, educaçăo essa que constrange aquele que filosofa a agir de acordo com o paradigma imutavelmente verdadeiro e causal de todas as coisas, logo, porque ele sabe o que deve fazer para garantir o bem de sua comunidade, pois, de fato, conhece o bem, necessariamente deve governar. Ou seja, segundo A República, năo há outra alternativa de bom governo a năo ser aquela em que quem governa sabe o que faz e, assim, de acordo com seu conhecimento acerca das ideias imutáveis, age no plano mutável e circunstancial político visando cumprir o papel ideal da política, a saber, colocar-se em prol da comunidade como um todo, instaurando a felicidade de se viver junto.

Na medida em que a filosofia confere o saber imutável e paradigmático da ideia, necessariamente, todos os que ascenderem ao conhecimento filosófico chegarâo ao mesmo modelo, sem sombra de variaçâo. Desse modo, sejam um, dois ou cem filósofos, o conhecimento do bem inteligível concretizar-se-á na mesma açăo no topos sensível, pois o saber que os rege confere ser e irrecusável verdade a suas decisóes, o que torna 
impossível a penumbra de qualquer tipo de divergência ou dissensâo. Ora, quando Sócrates desenvolve a tipologia de formas políticas, atenta para o fato de que a monarquia e a aristocracia, portanto, diferiráo apenas na quantidade de filósofos. Caso, na polis, surja apenas uma natureza filosófica educada na contemplaçâo luminosa das ideias, ela deve ser coagida a governar, tornando-se, desse modo, indiscutível rainha. No entanto, se a polis tiver sido agraciada com mais de um filósofo, logo, devem assumir a direçăo política todos os que compartilham tal natureza, sem que nenhum deles fique de fora, perfazendo, entăo, o governo dos melhores na medida em que săo os únicos aptos a decidir os rumos da cidade de modo necessariamente justo e feliz.

Assim, qualquer forma política que náo sejam a monarquia ou a aristocracia filosófica é degenerada e sequer pode ser nomeada no topos sensível como política, uma vez que esta, por definiçăo, refere-se ao governo exercido em favor do bem comum, suplantando qualquer tipo de privilégio. Com efeito, o único governo que responde a tal definiçăo é aquele cujo filósofo está no comando, pois só ele sabe adotar açōes em prol do bem de sua comunidade como um todo. Logo, a verdadeira política é aquela cujo filósofo é porta-voz.

Posto isso, note-se que a oligarquia, segundo Sócrates, nâo é, como diz Bobbio, “a forma corrompida da aristocracia", pois a forma degenerada do governo dos filósofos é a timocracia. Lembremos que a tipologia d'A República năo é a mesma que aquela apresentada na Política aristotélica. Se, em Aristóteles, a oligarquia é o governo dos poucos ricos, desvio da aristocracia, cujo governo se encontra nas măos dos mais virtuosos que visam o bem comum, no diálogo platônico, algo diferente acontece. Lá, o governo filosófico náo encontra uma forma correspondente desviada, precisamente porque todas as outras formas de governo resultam na degeneraçăo da única possibilidade virtuosa e verdadeira da ocupaçăo de cargos públicos. Nesse sentido, para Aristóteles, se a democracia, governo dos muitos pobres que conduzem as decisóes políticas visando apenas seus interesses, descurando das camadas ricas da populaçâo, é a forma corrompida da politeia, regime esse no qual toda a comunidade está em pé de igualdade em virtude, no diálogo platônico, tal raciocínio năo se aplica, pois a democracia é apresentada como corrupçâo da já corrompida oligarquia. Em outros termos, os regimes corrompidos d'A República seguem uma lógica diferente daquela apresentada na Política. Enquanto para Aristóteles a oligarquia, a democracia e a tirania săo três formas desviadas de regimes retos, no diálogo platônico, tais constituiçôes săo degeneraçôes de si mesmas. Assim, a timocracia degenera em oligarquia, que, por sua vez, quando se corrompe mais, torna-se democracia para, entâo, degringolar no pior de todos os regimes, a saber, a tirania.

Por fim, considerando o segundo extrato bobbiano, gostaria de argumentar que a afirmaçăo de que n'A República "as formas boas săo aquelas em que o governo năo se baseia na violência, e sim no consentimento ou na vontade dos cidadăos; onde ele atua de acordo com leis estabelecidas, e nâo arbitrariamente" provém de uma leitura irresponsável do diálogo de Platăo. Com efeito, nas formas boas, ou seja, virtuosas, a saber, na monarquia ou aristocracia filosóficas, o governo fundamenta-se na ideia do bem que ilumina com ser e verdade a constelaçấo de ideias imutáveis que devem reger a açăo do verdadeiro político. Consentimento ou vontade dos cidadâos é uma variável com a qual o campo da imutabilidade do conhecimento da ideia náo lida. Se o filósofo atua "de acordo com leis estabelecidas", é precisamente porque ele mesmo 
as instaura de acordo com seu conhecimento. As ideias regulam a açăo filosófica, mas ao mesmo tempo, é o filósofo que legisla na comunidade ideal, tornando-se a seus concidadăos o paradigma a ser seguido, independentemente, de possíveis discordâncias. Porque o filós ofo conhece, deve governar. Porque o filósofo conhece o bem, agirá bem. Sua alma una e cordata reflete a paz para a qual a política se destina. Assim, porque ele sabe o significado do termo política, já que experiencia todos os dias em si mesmo o microcosmo da felicidade decorrente do conhecimento da série causal que o torna agente das indiscutivelmente sábias decisōes, visará a felicidade de toda a sua comunidade, estendendo macrocosmicamente sua própria alma.

Razôes para discordarmos do diálogo platônico năo nos faltam, assim como também para com ele concordar. No entanto, a compreensăo do texto contextualizado em um gênero dialógico, bem como a reflexăo acerca tanto dos fundamentos que estruturam a argumentaçăo sobre a kalipolis quanto das degeneraçōes governamentais sâo essenciais para o início da apropriaçăo do início da primeira camada. Os livros V, VI e VII d'A República, nos quais as noçōes de rei-filósofo, do estabelecimento da diferença entre ciência, opiniâo e ignorância e da alegoria da caverna sâo desmembradas, nâo à toa preparam o terreno para a discussăo sobre a tipologia dos regimes. Tentar compreender tais regimes em detrimento daqueles livros é recusar ao clássico a luz que confere verdade e ser a existência de uma escrita que só se tornou possível graças aquilo mesmo que ela tenta ocultar. 


\section{REFERÊNCIAS BIBLIOGRÁFICAS}

BENVENISTE, E. Le vocabulaire des institutions indo-européenes. 2. Pouvoir, droit, religion. Paris: Éditions de Minuit, 1969.

BOBBIO, N. "A democracia dos modernos comparada à dos antigos (e à dos pósteros)". In: BOBBIO, N. Teoria geral da política: A filosofia política e as liçōes dos clássicos. Org. Michelangelo Bovero. Trad. Daniela Beccaccia Versiani. Rio de Janeiro: Campus, 2000, pp. 371-386.

. A teoria das formas de governo. Trad. Sérgio Bath. Brasília: UnB, 1985.

PLATÂO. A República. Traduçâo: Anna Lia Amaral de Almeida Prado. Sáo Paulo: Martins Fontes, 2006. 